\title{
MICHAŁ BORODO
}

https://orcid.org/0000-0002-9634-7097

Kazimierz Wielki University, Bydgoszcz

michal.borodo@ukw.edu.pl

\section{"HE SAW A BLACK MAN IN THE STREET, BUT NOT A CANNIBAL". TRANSLATION AND POLITICAL CORRECTNESS*}

\begin{abstract}
The article focuses on Kaytek the Wizard, the English translation of Janusz Korczak's children's classic Kajtuś czarodziej, originally published in Poland in 1933. Translated by Antonia Lloyd-Jones, the book came out in English with the New York-based Penlight Publications in 2012, almost eighty years after the original publication. The article begins with an overview of the theoretical context of translating children's literature, with regard to issues such as censorship, political correctness, and ideological manipulations. It demonstrates that contentious passages have often been mitigated, in order to create a commercially or ideologically "appropriate" text, for example in the former countries of the Eastern Bloc, in Spain, or in the contemporary United States. It then describes the context of the publication of the English version of Korczak's novel, shedding light on the roles of the copyright holder and translation commissioner, the publisher and the translator, and also mentioning the English language reviews of the translation in literary journals. Following that, the article examines the translator's treatment of the original expressions and passages concerning racial issues, which would be considered racist today. These include references to Africans as "savages", "apes" or "cannibals", a reflection of the European racial stereotypes of that period. It is demonstrated that, in her treatment of such lexical items, the translator adopted a middle course, retaining some of the contentious passages but also partly omitting and toning down other controversial
\end{abstract}

* This article was originally published in Polish in Przektadaniec 2016, vol. 33, pp. 196213. The English version was published with the financial support from the Polish Ministry of Science and Higher Education (DUN grant). 
examples in question. The article also reflects on the role of, and constraints on, the literary translator, who may be confronted with the ethical dilemma of either respecting the integrity of the original, and recreating the collective consciousness of a bygone era, or appropriating the original text, through eliminating passages which negatively portray blacks, so as to better adapt it to the target context of multicultural American society.

Keywords: political correctness, children's literature translation, literary translation, Janusz Korczak

\section{Korczak's classic eighty years later}

The article discusses Janusz Korczak's 1933 novel Kajtuś czarodziej and its English translation by Antonia Lloyd-Jones, Kaytek the Wizard, published in 2012 by the New York-based Penlight Publications, with financial support from the Polish Book Institute, the copyright holder of Korczak's whole output at the time. Published almost eight decades after the Polish original, this translation constitutes very interesting research material for a number of reasons. Firstly, the question arises how the translator rendered Korczak's style, which is often overly laconic and highly elliptical. Secondly, it is worth analysing how Lloyd-Jones treated cultural references concerning Polish social life, history and folklore. Thirdly, it would be interesting to see how the translator approached passages referring to racial issues, which recur in the Polish original yet are clearly politically incorrect by today's standards. It is this third aspect - the representation of Korczak's black protagonists in the English translation - that constitutes the focus of the present article.

Thus, the aim of the article is to establish what strategy was adopted by Antonia Lloyd-Jones in her translation, addressed to the American reader in the age of political correctness. Did the translator meticulously recreate the author's way of thinking, out of respect for him and his work as an artistic whole? Or did she suggest a new interpretation of the text, modernising the problematic passages, which would not be unjustified given the target culture, namely the multicultural American society? Finally, what role was played in this context by the institutional patrons of this translation project? Before addressing these questions, let me outline the theoretical context of translating for children and define the concept of political correctness. 


\section{Translating children's literature vis-a-vis political correctness}

At the turn of the 21st century, translation scholars researching children's literature often examined the influence of political and ideological conditions on translation. They looked at how retranslations of children's classics reflected ideologies dominant at a given time (e.g. Wunderlich 1992; Seago 1995; Dollerup 1999), studied censorship and manipulation (Craig 2001; Mdallel 2003; Thomson-Wohlgemuth 2003, 2006, 2009; Pokorn 2012), as well political correctness and its influence on the final form of the target text (Fernández López 2006; Thomson-Wohlgemuth 2004). It is worth noting that, in this respect, children's literature constitutes rewarding research material. Not infrequently, especially in the case of older translations, it is subject to various kinds of modification aimed at reducing or eliminating content deemed unsuitable for the young reader. To claim that this is typical of all translated texts for children would be an unjustified generalisation, especially with respect to contemporary translations; after all, many works of children's literature contain irony or a non-standard sense of humour, and these elements are often fully rendered in translation. However, interventions concerning such topics as death, violence, religion, sexuality, the body, racial issues, criticism of adults etc., abound in translated books for children (see e.g. Van Coillie 2013).

There are many examples. Good cases in point are: censoring the winedrunk Gulliver's chosen way of putting out a fire in the Lilliput palace (O’Sullivan 2005: 87), removing religious education from prince Giglio's school report card in Polish 1950s editions of The Rose and the Ring (Adamczyk-Garbowska 1988: 157), or various ways of attenuating Alice's fall into the bottom of the rabbit hole, depending on various English adaptors' creativity (Shavit 1986: 90). Similarly, Polish translations, not to mention Disney's picture book adaptations, also tend to more or less "cushion" Alice's hitting the ground.

Due to the distinctive addressee and lower cultural status of children's literature, the original text is sometimes modified, in accordance with the translator's or publisher's ideas as to what is and is not appropriate at a given stage of development. It can be assumed that children's literature will be all the more prone to modifications of politically incorrect passages, i.e. such uses of language as may be potentially offensive, harmful, disparaging and/ or reproduce prejudices and stereotypes concerning representatives of other races, ethnic minorities or social groups. 
The practice of modifying or eliminating content regarded as "inappropriate" has had a long tradition and has occurred at different times in history, e.g. in non-democratic countries, where children's books were subject to censorship. For example, having analysed documents drafted by censors in East Germany, Gabriele Thomson-Wohlgemuth notes that books such as Pippi Langstrumpf or Doctor Dolittle had a rather "complicated publishing history" due to their "improper depiction of black people" (ThomsonWohlgemuth 2004: 120). For this reason, following long negotiations with Astrid Lindgren and the son of Hugh Lofting, several chapters were excised from these novels (Thomson-Wohlgemuth 2004: 120). As we learn from Robert Looby's book (2015), in the People's Republic of Poland, translations from English-language literature were not subjected to measures as radical as the removal of entire "inappropriate" chapters. However, with regard to literature addressed to the adult reader, Looby notes a distinct tendency to mitigate or omit references to race that were considered offensive, such as "nigger", which was usually consistently rendered as "Murzyn" [Negro] (Looby 2015: 135-154). Interestingly, the same translation convention of neutralizing pejorative racial references is noticeable already in pre-war translations. In the case of translations of English children's literature, ideological interventions involving omitting or mitigating potentially inappropriate or incorrect content are rather rare and superficial; what seems more significant, especially in certain periods, is the preselection and withdrawal of texts from circulation (Looby 2015: 158).

Today, as Emer O'Sullivan observes (2005: 86), censorship is applied to children's literature e.g. in the U.S. context, and concerns, among other things, the elimination of illustrations containing nudity. Other examples of interference in the American context have been indicated by ThomsonWohlgemuth (2004: 120-121) with respect to Andersen's fairy tales, from which editors removed, for example, fragments concerning violence, the body, religion, disrespect towards adults, and - propelled by a politically correct sensitivity towards racial issues - replaced the term "black magic" with "bad magic", etc. The result of this kind of bowdlerization is a text that is significantly impoverished in terms of meaning and devoid of its previous multidimensionality; it is, however, undoubtedly "proper" and "appropriate" in the commercial and ideological sense. Thomson-Wohlgemuth points to certain analogies between the above-mentioned practices applied in the Eastern Bloc countries and those occurring in the American context: both cases involve censoring content - pertaining to religion, the body, violence, 
colonialism or racial issues - which is a priori considered inappropriate for the young reader or ideologically objectionable.

The issues surrounding race and political correctness in translation for children were addressed by Marisa Fernández-López (2006), who compared successive editions of Spanish translations of children's literature with their English counterparts. The researcher established that while the English source texts were subject to editorial revisions over time, and consequently became more politically correct, the subsequent editions of the same Spanish translations remained unchanged in this respect. The successive Spanish editions of a translation of one of Enid Blyton's novels still contain passages that create a negative image of the Roma and Africans, even though these fragments are no longer present in the revised editions of the original. In newer English editions of Hugh Lofting's The Story of Doctor Dolittle, lexical interventions are observable (e.g. the phrase "white man" is replaced by "man" or "European", while "black man" is replaced by "man" or "African"). There are also far-reaching modifications consisting in the removal of paragraphs or chapters considered politically incorrect (Fernández 2006: 50-51). The Spanish text does not exhibit such changes. Similar alterations appear in Roald Dahl's novel Charlie and the Chocolate Factory, and concern references to the skin colour and origin of Willy Wonka's chocolate factory workers, the Oompa Loompas. While in the subsequent English editions these references were radically changed, this was not the case with the Spanish editions. Thus, a sentence which in the modified, politically corrected English edition reads, "His skin was rosy-white, his long hair was golden-brown, and the top of his head came just above the height of Mr Wonka's knee", has the following equivalent in the unchanged Spanish version: Su piel era casi negra, y la parte superior de su lanuda cabeza llegaba a la altura de la rodilla del señor Wonka [His skin was almost black, and the top of his woolly head reached just above $\mathrm{Mr}$ Wonka’s knee] (Fernández 2006: 51). Fernández sees the reason behind these discrepancies in socio-historical differences between the two cultures. She also argues that fidelity to the first English edition may be related to the prestige that English literature for children enjoys in Spain. ${ }^{1}$

${ }^{1}$ In this context, the question arises about Polish translations of these children's books: do they tend to undergo modification in subsequent editions like the English source texts, or do they rather take the direction of the Spanish translations and their intact political (in)correctness? The answer would require a separate article, presenting a detailed analysis. To give only one example, in the new Polish translation of Roald Dahl (2015, trans. Magda Heydel), 
Political correctness is a complex phenomenon. According to Geoffrey Hughes (2010), on the one hand it involves mitigating and toning down potentially harmful or offensive content, combating prejudice and stereotypes by means of new or neutral-sounding phrases, making up for historical injustices, and providing equal opportunities for marginalised groups. On the other hand, it is perceived as a kind of semantic engineering, which, although driven by noble motives, imposes artificial and abstract language codes, sometimes hindering open exchange of views and bringing to mind the Orwellian newspeak. The influence of political correctness on children's literature, as the abovementioned examples indicate, is visible in the activities of publishers, especially in the U.S., who make sure that books for young readers are published in line with the standards of political correctness (Hughes 2010: 248-249). This applies to titles such as The Story of Doctor Dolittle, The Adventures of Tintin, Adventures of Huckleberry Finn, as well as Enid Blyton's books. For example, the Tintin series, published since 1929 and depicting non-European cultures in a rather stereotypical way, has been harshly criticised, e.g. in 2007 when complaints were made, both in Belgium and the U.K., about its racial prejudices against Congolese indigenous people (Hughes 2010: 248-249). Another example of such criticism is the controversy around the word "nigger" in Adventures of Huckleberry Finn, first published in 1884. Today the term is regarded as offensive; however, as Lionel Trilling observed, this was the only word Huck could know, being as he was a rough uneducated boy in the American South before the Civil War. This might not be a commendable fact, but a historical one nonetheless, which is worth confronting rather than forgetting or passing over in silence (Hughes 2010: 152).

\section{Kajtek czarodziej, Kaytek the Wizard: The publishing context}

First published in 1933, Kajtek czarodziej is the story of a restless boy with a lively imagination, who dreams of mastering the art of magic. When his dream comes true, despite his best intentions Kajtek is not always able to make good use of his magical abilities. Failing to foresee the consequences of his actions, he wreaks havoc in Warsaw: he turns back all the clocks by a few hours, makes the inhabitants of the capital walk backwards, and con- 
jures up a mysterious island and palace in the middle of the Vistula River. After these extraordinary events, Kajtek sets off on a journey abroad and has a number of fantastic adventures; he becomes a boxer in a Parisian circus, an actor in Hollywood, and he even gets transformed into a dog, struggling to find his way home. Kajtuś Czarodziej is therefore a novel about growing up, a story of a child protagonist who grows more mature with experience, gaining knowledge about human limitations, free will and responsibility for his own actions.

Before focusing on the novel itself, let us briefly introduce the author and the translator. The author of the original, Janusz Korczak (the pen name of Henryk Goldszmit), was a Polish-Jewish pedagogue and pediatrician, an acclaimed children's writer and the author of the all-time Polish classic Król Maciuś Pierwszy [King Matt the First]. In pre-war Poland, he ran his own radio programme about children's rights and was the head of a Warsaw orphanage for Jewish children, known for his innovative pedagogical methods. He died in the summer of 1942, killed in the Nazi German concentration camp in Treblinka, together with the children from his orphanage, whom he had refused to abandon.

Antonia Lloyd-Jones, a graduate of Oxford University, is an acclaimed translator of Polish literature into English. She has translated novels, life writing and reportage, including books by Zygmunt Miłoszewski, Paweł Huelle, Olga Tokarczuk, Joanna Olczak-Ronikier, and many other authors. Lloyd-Jones is a double recipient of the Found in Translation award, an annual distinction for the best literary translation from Polish into English, established in 2008 by the Kraków-based Polish Book Institute, the Polish Cultural Institute in London, the Polish Cultural Institute in New York and the W.A.B. Publishing House in Warsaw. She first received it in 2009 for the translation of Paweł Huelle's novel The Last Supper (Ostatnia wieczerza), and then in 2012 for as many as seven translations published that year. Grzegorz Gauden, the then director of the Polish Book Institute, commented on this outstanding achievement as follows: "I'm impressed by their quality on the one hand, and on the other - by the translator's extraordinary diversity. (...) Within one year, she published a collection of short stories and a novel, a biography, a book of reportage, and a classic of young adult fiction" (Instytut Książki 2013). The classic of young adult fiction is of course Korczak's novel Kaytek the Wizard. In 2018, Antonia Lloyd-Jones also received the prestigious Transatlantyk Prize, awarded to distinguished ambassadors of Polish literature abroad. 
The English translation of Kajtuś czarodziej was published at a special time: the year 2012 was officially proclaimed by the Polish parliament as the Year of Janusz Korczak, and abounded in events and initiatives devoted to the author and educator. Kaytek the Wizard appeared with the New Yorkbased Penlight Publications, in elegant hardcover and with black-and-white illustrations by Avi Katz. The publication was co-financed by the Polish Book Institute under the CPOLAND Translation Programme, which is aimed at increasing the international visibility of Polish literature in translation. Referring to theoretical concepts developed by André Lefevere (1992), one can say that, as the copyright holder and co-funder of this translation project, the Polish Book Institute played the role of its institutional patron, which means that potentially it could have had a significant influence on the refraction of the source text.

In this context, a good example is the choice of the main protagonist's name in the English title. Proposals considered in the course of translation preparation included such names as Willy the Wizard, Kazik and Casimir, which were the publisher's preferred options, and Titus, suggested by the translator as partly rhyming with the Polish Kajtuś (Lloyd-Jones 2012). The Polish Book Institute, in turn, stressed that the titles of Korczak's books should, as far as possible, remain unchanged. Having considered several versions, the translator finally opted for Kaytek, a name that sounds rather foreign to native speakers of English (Lloyd-Jones 2012).

In a 2012 interview, Antonia Lloyd-Jones also mentions that she did not want to include, in the English version, those of Korczak's expressions which would, today, be considered politically incorrect. However, in the afterword to her translation, she refers to this problem as follows:

Some phrases in the book sound extremely politically incorrect to the modern ear, but would not have been considered unusual when the book was written, such as pejorative references to black people as cannibals or apes, and to Jews as inferiors. Wishing to remain faithful to Korczak's original text, the publishers have chosen to leave these phrases as they were written. (Lloyd-Jones 2012: 269)

This suggests that the translator did not feel quite comfortable accurately rendering some potentially contentious phrases. As can be seen, the translator is the main but not the only agent determining the final shape of the target text.

The issue of the political incorrectness in Korczak's book was raised by an anonymous reviewer in New York's Kirkus Reviews magazine: 
The translation is excellent, and notes are provided to help readers understand local customs and geography. Unfortunately, the book suffers from mid-20thcentury European racism, particularly in its attitude toward Africa and Africans. Students of children's literature will find the book and the afterword illuminating. Children will need to place it in historical perspective. Illustrated with full-page black-and-white art. Fascinating but flawed. (Kirkus Reviews 2012)

A similar comment was made by Sharon Elswit, in a review published on the Jewish Book Council website. The reviewer notes: "Left in are a few uncomfortable references reflecting speech of that time where Africans are cannibals", concluding that Kaytek the Wizard should be treated as a "novel of historic interest, rather than as one to recommend for young readers now" (Elswit [undated]). In light of these examples of critical reception, it is worth asking whether the translator of the "flawed" pre-war novel indeed left the politically incorrect expressions intact, or whether she perhaps decided to introduce some modifications into her English version.

\section{Savages, cannibals and "black creatures"}

In Kaytek the Wizard, expressions which today would mostly be considered politically incorrect concern mainly racial issues, such as the image of Africans. The first such reference appears in the opening of chapter three:

ST: Widział Kajtuś na ulicy takiego Murzyna, ${ }^{2}$ ale nie ludożercę. (Korczak 1985: 29)

TT: Kaytek once saw a black man [Negro] in the street, but he wasn't a cannibal. (Korczak 2012: 37)

Such references can be regarded as reflecting the collective consciousness of interwar Poland; in this racially homogeneous society a person with black skin was probably perceived mainly through the prism of literary characters such as Friday from Robinson Crusoe or Kali from Henryk Sienkiewicz's 1911 young adult novel In Desert and Wilderness (mainly known in English

${ }^{2}$ With the non-Polish-speaking reader in mind, problematic words or phrases have been set in bold type in excerpts from Korczak's text, and their literal (or at least more accurate) equivalents have been provided in square brackets alongside Antonia Lloyd Jones's lexical choices. 
as Through the Desert). Korczak's novel can also be interpreted more broadly as an example of European colonial attitudes. Although the Second Polish Republic did not rule over any overseas territories, it did entertain some colonial aspirations, visible for example in the activities of the Maritime and Colonial League, with a million members at its peak. The interest in this subject is also apparent in travel writing and young adult fiction, which constituted part of the Polish literary scene throughout the 1930s (Borkowska 2007: 23). As Marek Arpad Kowalski points out, "this literature, popular yet of great artistic merit and skilful execution, created a «colonial» atmosphere. Meant for readers of virtually all ages, it allured the young with fanciful exoticism and adventure" (Kowalski 2005: 327). The fascination with distant lands and exoticism is also echoed in Korczak's writing.

In the original Polish Kaytek the Wizard, there are three references to cannibals in total. The other two have also been consistently preserved in the English translation:

ST: Poczekajcie - odgraża się Kajtuś. - Niedługo kończy się miesiąc. Niech się dorwę do czarów, zaraz cała szkoła pofrunie do ludożerców. (Korczak 1985: 64).

TT: "Just you wait", thought Kaytek. "The month will soon be over. Just let me go into some magic spells and the whole school will fly off to the cannibals". (Korczak 2012: 81)

ST: Dwa razy byłem rozszarpany: przez tygrysa i przez kulę armatnią. Topiłem się, trułem, wisiałem na szubienicy indyjskiej - w Afryce ludożercy ugotowali mnie w rosole z żółwi szylkretowych. Ale wszystko to głupstwo w porównaniu z dzisiejszą walką. (Korczak 1985: 144)

TT: I've been torn to pieces twice - once by a tiger and once by a cannonball. I've drowned, been poisoned, and strung up on an Indian gallows - in Africa I was boiled by cannibals in a stock made of hawksbill turtles. But all that's nothing compared with today's fight. (Korczak 2012: 176-177)

One should bear in mind that these expressions appear in an adventure novel for children and young adults. Although they undoubtedly exemplify a distorted and stereotypical image of Africans, today we might take a tongue-in-cheek approach toward them, noting their humorous overtone. They reflect a worldview from a different age and a different cultural context.

Similar observations concerning sensibilities characteristic of a bygone era can be found in Piotr Blumczyński's and Joanna Woźniczak’s article 
"From an American Plantation to Interwar Poland: How Uncle Remus Became Bam-bo the Negro" (2013). The authors discuss the 1929 Polish translation of Joel Chandler Harris's Uncle Remus stories, which portray the American South, with all the details of its local colour. On the one hand, Blumczyński and Woźniczak point to the translator's considerable departures from the source text, concluding in metaphorical terms that "in his journey from an American plantation to interwar Poland, Uncle Remus [a former slave - M.B.] lost his identity, dignity and the key role he played in the original book" (Blumczyński, Woźniczak 2013: 157). The Polish translation, they argue, is "an interesting testimony of cultural stereotypes of the time" (ibid. 158). On the other hand, they rightly note that "negative racial stereotypes (...) are more striking today than eighty years ago" (ibid. 154). Thus, from their analysis it may be inferred that it would be unfair to blame the translator for exhibiting a different sensibility in this respect. The article by Blumczyński and Woźniczak brings to mind Judith Lavoie's (2007) similar discussion of the first French translation of Adventures of Huckleberry Finn, in which Jim is transformed into an inferior and subservient protagonist, devoid of the dignity he has in the original book, where he is portrayed as an experienced man treating Huck in a fatherly manner.

Apart from the above-listed references to cannibals, Korczak's novel also contains other, somewhat more problematic descriptions. Most of them appear in chapter thirteen, which tells about Kaytek's boxing fight against a black athlete in a circus in Paris. Let us look at selected passages describing this event, starting with the black boxer's appearance in the arena:

ST: Wychodzi Murzyn. Łyska białkami oczu. Pokazuje w uśmiechu białe zęby. Kłania się. Grzmot oklasków. Ktoś rzucił kwiaty, ktoś inny - pomarańcze. Murzyn zajada, oblizuje się, gładzi się po brzuchu. (Korczak 1985: 138)

TT: At last - out comes the African. The whites of his eyes are shining. He smiles, flashing his white teeth. He bows. There's thunderous applause. Someone throws flowers, someone else throws tomatoes. The African eats them, licks his lips, rubs his stomach. (Korczak 2012: 170)

This excerpt portrays the African in a stereotypical way. The nameless black man has "shining eye whites"; he "flashes his white teeth" and "rubs his stomach", having eaten the tomatoes the audience throw (at?) him. In the Polish source text, they were throwing oranges; the change in translation strengthens the audience's negative attitude towards the athlete. It is 
worth noting the translator's use of the neutral word African. Lloyd-Jones consistently chooses it over more pejorative words to render the original Murzyn [Negro], czarny [black one], or dziki [the savage].

When the boxer sees that he is to fight against a boy hiding his face behind a red mask, at first he is surprised and amused, then concerned:

ST: Murzyn też myśli, że to żart białych panów. (Korczak 1985: 139)

TT: The African also thinks the white guys [masters] are having a joke. (Korczak 2012: 171)

ST: Murzyn zakłopotany patrzy na Kajtusia. On jeden może poznał, bo dziki wierzy w czary.

- Czarny się boi. Patrzcie. Niech żyje Czerwona Maska! (Korczak 1985: 140)

TT: The confused African looks at Kaytek. He alone may have realized Kaytek's secret, because some Africans [the savage] believe in magic.

“Look! The African [black]'s afraid. Long live the Red Mask!" (Korczak 2012: 171)

Both these passages involve some noticeable translation modifications. First of all, the negatively charged sentence "dziki wierzy w czary" [the savage believes in magic/witchcraft] has been rendered as "some Africans believe in magic". In this way, the pejorative term "savage" has been removed, and as a whole the English sentence can be read as a reference to different traditions and rites rather than superstition and backwardness, as potentially suggested by the original. Secondly, the phrase "żart białych panów" [white masters' joke] has been translated as "the white guys are having a joke". Instead of "white masters", an expression resonant with the history of colonialism and slavery, the translator opted for a colloquial and more neutral-sounding term. At the same time, one should note that the reference to skin colour is only muffled in the case of "the Negro", but not in the case of "white masters"; thus, the African's otherness and the hierarchical relationship between races, so clearly outlined by Korczak in 1933, is still implied in the translation. Theoretically, it would have been possible to erase all references to skin colour altogether. In light of the previously cited examples, provided by Fernández and Thomson-Wohlgemuth, from the point of view of the target culture such a treatment of the original probably would not have been unheard of. From the perspective of the source culture, 
however, such a procedure could appear as radical and far-fetched, an unjustified interference exemplifying the occasional situation where political correctness slips into caricature (cf. Hughes 2010). To sum up, in both the above instances one can notice the translator's interventions mitigating the negative overtones of Korczak's original.

As the scene unfolds, the African boxer is again presented in a stereotypical way; no longer by means of terms such as "black one" or "savage" (which the translator consistently avoids), but in even more pejorative expressions, coming from the audience excited by the fierce fight:

ST: Nie daj się, czarny! Zuch Czerwona Maska! Precz z małpą! Szympans, goryl! Murzyn już się nie śmieje (Korczak 1985: 140).

TT: Don't give up, African [black one]! Well done, Red Mask! Down with the monkey! Chimp! Gorilla! The African [Negro] isn't laughing any more. (Korczak 2012: 172)

In the 21 st century, these racist remarks cause uneasiness or even embarrassment. This is probably one of the moments in the book where an adult reading Korczak's novel aloud with his or her child would probably rub his or her eyes in astonishment, perhaps decide to pause or even skip this passage in loud reading. In this particular instance, an intervention in the text would not have been unjustified; perhaps it would have worked in favour of the original author's image, as well as the reader him- or herself, who otherwise may be puzzled by the expressions used and the worldview emerging from Korczak's novel. That said, the question arises how far translators can go in their interventions, to what extent they are allowed to adapt the source text to their own beliefs and point of view, and how much room is left for such modifications if the translator also needs to take into account the guidelines of publishers, editors, and institutional patrons.

To return to Korczak's text, the black boxer gets compared to a beast also further on in this scene; there is an emphasis on his animalistic features:

ST: Kołysząc się pochylony - Murzyn z krwią nabiegłymi oczami idzie na Kajtusia. (...) Olbrzymia czarna łapa mierzy w głowę Kajtusia. (...) Posypały się uderzenia drobnej ręki. Mięśnie Murzyna drgają pod skórą. (Korczak 1985: 141)

TT: Rocking and leaning forward with bloodshot eyes, the African is coming toward Kaytek. (...) The African aims an enormous black paw at Kaytek's 
head. (...) Kaytek's small hand showers punches on the African, whose muscles are twitching under the skin. (Korczak 2012: 174)

At the climax of this scene, Korczak's suggestive description of the African "with bloodshot eyes" and "twitching muscles", aiming "an enormous black paw" at the boy, sounds almost like an account of a man's fight against a half man half beast, an ape, a wild ferocious opponent driven by animal instinct, ready to attack at any moment.

What happens later, when the fight is resolved, is one of the most evocative moments underscoring hierarchic racial relations between the victorious white boy and the defeated African:

ST: Murzyn zbliża się - stawia nogę Kajtusia na swym karku. Kajtuś otwiera oczy, z wysiłkiem wyciąga ręce. Murzyn opiera głowę na jego kolanach; Kajtuś całuje go w głowę, gładzi kędzierzawe kudły.

Ludzie płaczą. Huragan oklasków. Olbrzym bierze Kajtusia na ręce ostrożnie ostrożnie i wynosi z areny. (Korczak 1985: 142)

TT: The African comes up and places Kaytek's foot on the back of his own neck. Kaytek opens his eyes, and stretches out his arms with an effort. The African rests his head on Kaytek's knees; Kaytek kisses him on the head, and strokes his curly hair.

People are crying. There's a hurricane of applause. The giant gently picks Kaytek up and carries him out of the arena. (Korczak 2012: 174-145)

Admitting defeat to the boy, the black boxer bows his head in a gesture of submission and puts Kaytek's foot on the nape of his neck. This inevitably brings to mind colonial relations between a "white master" and a black servant or slave. At the same time, however, Korczak's description is ambivalent. Although it is the boy who wins the fight, he is then caringly picked up by the African and taken out of the circus arena, swooning, completely exhausted, at the mercy of the sturdy black opponent.

Particularly interesting, from the point of view of translation, is a description that appears at the end of the novel, in chapter twenty, which depicts Kaytek's airborne journey. Carried on the wings of the wind, the boy enjoys a bird's-eye view of the African continent:

ST: Widzi palmy wysokie, dziwne zwierzęta i ptaki, czlowieka czarnego. Ubogie namioty, lepianki, nędzne rupiecie naczyń i sprzętów; cudaczne ozdo- 
by w uszach i w ustach. Trudno w czarnym stworzeniu dopatrzyć się brata; trudno wierzyć, że biały człowiek, jak uczy historia, równie dziki był dawno, kiedyś, przed laty. (Korczak 1985: 218)

TT: He sees tall palm trees, strange animals and birds, and people with black skin [the black man]. They live in poor tents or mud huts and have miserable bits of junk for utensils and equipment. They have weird decorations in their ears and lips. When you study history, [it's hard to see a brother in the black creature] it's incredible to think that white men lived just the same way as them [were just as savage] a long, long time ago. (Korczak 2012: 259)

The last sentence of the original excerpt deserves special attention. It begins with the words "Trudno w czarnym stworzeniu dopatrzyć się brata", "it's hard to see a brother in the black creature", which did not make it into the English version. Antonia Lloyd-Jones decided to omit this fragment altogether, probably due to its negative and racist message. The subsequent part of this description also exhibits a translatorial intervention: "trudno wierzyć, że biały człowiek (...) równie dziki był dawno, kiedyś, przed laty" [it's hard to believe that the white man (...) was just as savage once, many years ago] was rendered as "it's incredible to think that white men lived just the same way as them a long, long time ago". Thus, the contrast between "the wild African" and "the civilized white man" is partly mitigated in translation. The adjective $d z i k i$ [wild/savage] was again omitted.

\section{Searching for a compromise}

The above comparative analysis shows that, although the English translation of Korczak's novel features some interventions on the lexical level, they are not as far-reaching as those revealed in the studies by Fernández-López and Thomson-Wohlgemuth quoted at the beginning of the present article. At the same time, however, the above-cited English-language reviews of Kaytek the Wizard point to passages concerning racial issues as not being fully compatible with target culture norms. The article also sheds light on publishing conditions and the role that institutional patrons can play in the context of translating children's literature.

The analysis of descriptions concerning racial issues, in Korczak's book and its English translation, leads to the following question: how should such passages be treated in translation in the 21 st century? Facing such a dilemma, 
the translator may consider two radically different translation strategies. On the one hand, respecting the integrity of the original, he or she could treat it as a historical document, and accurately reproduce the author's way of thinking and thus show the collective European awareness of the interwar period. On the other hand, having in mind the contemporary target reader, a member of the multicultural American society, he or she could propose a completely new interpretation, modifying or eliminating potentially controversial descriptions which refer to other races or ethnic minorities in a depreciating way. The choice of the latter strategy would be ethically motivated, although it would also entail the risk of the translator being accused of unjustifiably appropriating the original text. In Kaytek the Wizard, Antonia Lloyd-Jones opted for a compromise: she modified and toned down some of the negative racial references, while leaving others unchanged. As she herself admits, controversial expressions remained in the text due to the influence of the patrons of this translation. After all, their role in making the original available to readers in a new cultural context is sometimes no less important than that of the translator himself or herself. The assessment of the compromise in Kaytek the Wizard will then depend on the subjective sensitivity, knowledge and beliefs of the individual reader of the translation.

Translated from Polish by Zofia Ziemann

\section{Bibliography}

Adamczyk-Garbowska M. 1988. Polskie ttumaczenia angielskiej literatury dziecięcej: problemy krytyki przekładu, Wrocław: Zakład Narodowy im. Ossolińskich.

Blumczyński P., Woźniczak J. 2013. "From an American Plantation to Interwar Poland:

How Uncle Remus Became Bam-bo the Negro", trans. P. Blumczyński, Przektadaniec 22-23 [English Version], pp. 147-159.

Borkowska G. 2007. "Polskie doświadczenie kolonialne", Teksty Drugie 4, pp. 15-24. Craig I. 2001. Children's Classics under Franco. Oxford: Peter Lang.

Dollerup C. 1999. Tales and Translation, Amsterdam: John Benjamins.

Elswit S. [undated]. "Kaytek the Wizard", http://www.jewishbookcouncil.org/book/ kaytek-the-wizard [access: 20 September 2018].

Fernández-López M. 2006 [2000]. "Translation Studies in Contemporary Children's Literature: A Comparison of Intercultural Ideological Factors", in: G. Lathey (ed.), The Translation of Children's Literature: A Reader, Clevedon: Multilingual Matters, pp. 41-53. 
Hughes G. 2010. Political Correctness: A History of Semantics and Culture, Chichester: Wiley-Blackwell.

Instytut Książki. 2013. "Found in Translation dla Antonii Lloyd-Jones", http://www.instytutksiazki.pl/wydarzenia,aktualnosci,29813, found-in-translation-dla-antonii-lloydjones.html [access: 10 September 2018].

Kirkus Reviews. 22.07.2012. "Kaytek the Wizard", http://www.kirkusreviews.com/bookreviews/janusz-korczak/kaytek-wizard [access: 20 September 2018].

Korczak J. 1985 [1933]. Kajtuś czarodziej, Warszawa: Nasza Księgarnia.

Korczak J. 2012. Kaytek the Wizard, trans. A. Lloyd-Jones, New York: Penlight Publications.

Kowalski M.A. 2005. Kolonie Rzeczpospolitej, Warszawa: Bellona.

Lavoie J. 2007. "Mark Twain vs. William-Little Hughes: The Transformation of a Great American Novel", in: P. St-Pierre, P. C. Kar (eds.), In Translation - Reflections, Refractions, Transformations, Amsterdam: John Benjamins, pp. 95-106.

Lefevere A. 1992. Translation, Rewriting, and the Manipulation of Literary Fame, London-New York: Routledge.

Lloyd-Jones A. 2012. Interview, http://culture.pl/pl/artykul/kajtus-kaytek-korczak-wywiad-z-tlumaczka-antonia-lloyd-jones [accessed: 10 September 2018].

Looby R. 2015. Censorship, Translation and English Language Fiction in People's Poland, Leiden-Boston: Brill/Rodopi.

Mdallel S. 2003. "Translating Children's Literature in the Arab World: The State of the Art”, Meta 48(1-2), pp. 298-306.

O'Sullivan E. 2005. Comparative Children's Literature, London: Routledge.

Pokorn K.N. 2012. Post-Socialist Translation Practices: Ideological Struggle in Children's Literature, Amsterdam: John Benjamins.

Seago K. 2006 [1995]. Nursery Politics: Sleeping Beauty, or the Acculturation of a Tale", in: G. Lathey (ed.), The Translation of Children's Literature: A Reader, Clevedon: Multilingual Matters, pp. 175-189.

Shavit Z. 1986. Poetics of Children's Literature, London: The University of Georgia Press.

Thomson-Wohlgemuth G. 2003. "Children's Literature and Translation Under the East German Regime", Meta 48(1-2), pp. 241-249.

2004. "Children's Literature in Translation East to West", in: S. Chapleau (ed.), New Voices in Children's Literature Criticism, Lichfield: Pied Piper Publishing, pp. $119-128$.

_2006. "Flying High - Translation of Children's Literature in East Germany", in: J. Van Coillie, W.P. Verschueren (eds.), Children's Literature in Translation: Challenges and Strategies, Manchester: St. Jerome, pp. 47-59.

- 2009. Translation under State Control: Books for Young People in the German Democratic Republic, New York-Abingdon: Routledge.

Van Coillie J. 2013. "No Sleeping Beauty without Thorns: A Model for Comparative Analysis Translated Fairy Tales", Przekładaniec 22-23 [English Version], pp. 7-32.

Wunderlich R. 1992. "The Tribulations of Pinocchio: How Social Change Can Wreck a Good Story", Poetics Today 13(1), pp. 197-219. 